\title{
The Postnatal Development of Sodium Transport in the Proximal Small Intestine of the Rabbit
}

\author{
R. W. SHEPHERD, M.B., B.S., M.R.C.P., J. R. HAMILTON, M.D., F.R.C.P.(C), AND \\ D. G. GALL, M.D., F.R.C.P.(C) ${ }^{(26)}$ \\ The Research Institute, The Hospital for Sick Children, Division of Gastroenterologv, Department of Paediatrics, \\ University of Toronto, Toronto, Ontario, Canada
}

\begin{abstract}
Summary
To investigate the postnatal development of intestinal $\mathrm{Na}^{+}$ transport, a major determinant of fluid absorption, we measured spontaneous and glucose-coupled $\mathrm{Na}^{+}$transport across short-circuited epithelium and in isolated villus enterocytes from rabbit jejunum at age intervals after birth. Villus cells from suckling animals actively transported $\mathrm{Na}^{+}$and responded to glucose, but their capacity to do so was less than that of villus cells from older animals. $\mathrm{Net} \mathrm{Na}^{+}$fluxes across short-circuited epithelium from suckling animals failed to respond to glucose, remaining negligible and less than adult values. This lack of response to glucose in tissue from younger animals was associated with marked paracellular shunting as evidenced by greater unidirectional fluxes and greater tissue conductance. Villus enterocytes from suckling animals compared to those from adults had reduced $\left(\mathrm{Na}^{+}-\mathrm{K}^{+}\right) \mathrm{ATPase}$ activity, but were rich in thymidine kinase. We conclude that proximal intestinal epithelium in suckling animals has a limited capacity for active $\mathrm{Na}^{+}$transport, is incompletely differentiated, and is leaky, with a greater permeability for ions compared with adult intestine.
\end{abstract}

\section{Speculation}

Changes which occur in intestinal $\mathrm{Na}^{+}$transport during postnatal development may be important in the pathogenesis of infant diarrhea, and relative limitations of intestinal transport capacity may contribute to the infant's susceptibility to dehydration following enteric infection.

Advances in our understanding of normal intestinal ion and water transport have contributed greatly to modern concepts of the pathophysiology and treatment of diarrheal disease $(1,18)$. The young of all species seem particularly susceptible to diarrhea. Development of the digestive and absorptive functions of the small intestine has been extensively studied $(10,13,15)$; but little information is available regarding intestinal electrolyte and water absorption during early postnatal life. Recent studies have suggested that changes occur in ileal transport function during development of the rabbit (4), and in the rat, altered intestinal response to hypertonic solutions has been shown in young compared with adult animals (22). The present study examines jejunal $\mathrm{Na}^{+}$ transport during postnatal development of the rabbit. Using established techniques, we measured spontaneous and glucose-coupled $\mathrm{Na}^{+}$transport in vitro across short-circuited jejunal epithelium and in isolated jejunal villus cells at intervals from birth to maturity. We focused our attention on sodium because this actively transported ion is a major determinant of the passive flow of water across the intestine (18).

\section{MATERIALS AND METHODS}

We studied nonfasted New Zealand White rabbits at ages 3 to 5 days ( 100 to $170 \mathrm{~g}$ ), 10 to 14 days ( 200 to $260 \mathrm{~g}$ ), 24 to 28 days
(300 to $350 \mathrm{~g}$ ), or as adults ( 1500 to $3500 \mathrm{~g}$ ). After weaning at 21 days, they received standard rabbit chow ad libitum. The animals were killed with an injection of Phenobarb sodium, and a $15-\mathrm{cm}$ segment of jejunum starting 5 to $10 \mathrm{~cm}$ distal to the ligament of Treitz was used for ion transport studies in short-circuited chambers or for isolation of villus enterocytes for $\mathrm{Na}^{+}$efflux studies and enzyme analyses. Steady-state unidirectional mucosa to serosa $\left(J_{\mathrm{ms}}\right)$, serosa to mucosa $\left(J_{\mathrm{sm}}\right)$ and net $\left(J_{\text {net }}\right) \mathrm{Na}^{+}$fluxes were measured in Ussing-type short-circuited chambers under basal conditions and after glucose $30 \mathrm{mM}$ by a modification of a technique previously described (16), exposing $0.4 \mathrm{~cm}^{2}$ mucosal and serosal surfaces of 4 adjacent segments of jejunal epithelium to $15 \mathrm{ml}$ of warmed oxygenated Krebs-bicarbonate phosphate buffer. Small $\left(0.4 \mathrm{~cm}^{2}\right)$ chambers were used for all age groups to minimize differences in villus surface area with age. Three consecutive 10 -min fluxes and 1 overall $30-\mathrm{min}$ flux were measured for each period after 15-min equilibration. The spontaneous potential difference (PD) was determined at intervals, and a shortcircuit current $\left(I_{\mathrm{Bc}}\right)$ appropriate to neutralize the electrical gradient was introduced (19). $\mathrm{Na}^{+}$fluxes were expressed as $\mu \mathrm{Eq} / \mathrm{cm}^{2} / \mathrm{hr}^{-1}$, $P D$ as $\mathrm{mV}, \mathrm{I}_{\mathrm{sc}}$ as microamps, and conductance as $\mathrm{mmho} / \mathrm{cm}^{2}$. Initially, the in vitro study of very fragile epithelium from these young, small animals presented certain technical problems. Because stripping the mucosa from underlying muscularis damaged the tissue of the younger rabbits, we studied full thickness intestine at all ages, first comparing $\mathrm{Na}^{+}$flux in stripped and unstripped tissue from adult rabbits. In unstripped tissue, $\mathrm{J}_{\mathrm{ms}}^{\mathrm{Na}}, \mathrm{J}_{\mathrm{gm}}^{\mathrm{Na}}, \mathrm{J}_{\mathrm{net}}^{\mathrm{Na}}$, and $\mathrm{I}_{\mathrm{sc}}(n=6)$ did not differ from values in stripped mucosa $(n=8)$ $\left(\mathrm{J}_{\text {net }}^{\mathrm{Na}}\right.$, stripped versus unstripped, $0.02 \pm 0.57$ versus $1.05 \pm 0.53$ $\mu \mathrm{Eq} / \mathrm{cm}^{2} / \mathrm{hr}$; mean \pm S.E.); in both tissue preparations. $\mathrm{J}_{\text {net }}^{\mathrm{Na}}$ and $\mathrm{I}_{\mathrm{sc}}$ were equally stimulated by glucose ( $\mathrm{J}_{\text {net }}^{\mathrm{Na}}$ stripped, $2.92 \pm 0.63$; unstripped, $3.08 \pm 0.88, P<0.001$ ). Tissue conductance across stripped intestine was significantly greater than that across full thickness mucosa throughout the experiment in the absence or the presence of glucose $(P<0.001)$. The Ussing chamber data for the 3- to 5-day-old rabbits is not presented because the tissue failed to maintain stable electrical characteristics and histologic sections taken after the experiment showed exfoliation of cells and mechanical damage. In all other age groups, histologic sections taken after the experiment showed minimal abnormality, and the electrical characteristics of the tissue remained stable for at least $2 \mathrm{hr}$ under the conditions of the experiment.

Villus cells could be selectively and reliably isolated from jejuna in all age groups by a vibration technique which excludes crypt cells (7); the presence of intact crypts was confirmed by light microscopy after the isolation procedure. The technique for $\mathrm{Na}^{+}$ efflux studies using these villus cells was identical to that described previously (7-9). Briefly, $\mathrm{Na}^{+}$efflux rate constants were measured after loading the enterocytes with ${ }^{22} \mathrm{Na}^{+}$, washing with $\mathrm{MgCl}_{2}$, resuspending them in a tracer-free medium, and measuring the rate of appearance of ${ }^{2 t} \mathrm{Na}^{+}$in the medium, expressed as the amount of $\mathrm{Na}^{+}$exchanged per hr. Rate constants were studied with and without maximal inhibition by ouabain $1 \mathrm{mM}$, defined as passive and total efflux (7), respectively, in both a glucose-free 
(mannitol, $10 \mathrm{mM})$ and glucose $(10 \mathrm{mM})$-containing medium. Isolated villus cells were also homogenized (9) and assayed for sucrase and lactase by the method of Dalhquist (5), $\mathrm{Na}^{+} \mathrm{K}^{+}$ ATPase by a modification (9) of the method of Kelly et al. (11), thymidine kinase by a modification (9) of the method of Klemperer and Haynes (12) and Breitman (3), and protein by the method of Lowry et al. (14).

Results were analyzed by Student's $t$ test or paired $t$ test where appropriate. Analysis of enzyme data were based on a logarithmic distribution, and the results were expressed as antilogarithms.

\section{RESULTS}

\section{SHORT-CIRCUIT CHAMBER STUDIES}

$\mathrm{Na}^{+}$Flux (Table l). Net fluxes under basai (glucose-free) conditions did not differ significantly between the age groups studied. Glucose produced expected significant increments in $\mathrm{J}_{\text {net }}^{\mathrm{Na}}$ and $\mathrm{J}_{\mathrm{ms}}^{\mathrm{Na}}$ in intestine from 24- to 28-day and adult animals resulting in net absorption of $\mathrm{Na}^{+}(P<0.005)$, whereas in contrast, fluxes across intestine from 10- to 14-day animals failed to respond to glucose. Unidirectional fluxes, $\mathrm{J}_{\mathrm{ms}}^{\mathrm{Na}}$ and $\mathrm{J}_{\mathrm{sm}}^{\mathrm{Na}}$ were significantly greater in the absence or presence of glucose in the 10- to 14-day age group compared with that in older animals and decreased progressively with increasing age.

Electrical Data (Fig. 1). Throughout the basal study period, mean PD of tissues from all age groups remained stable, and no significant differences were observed between groups. After 30 $\mathrm{mM}$ glucose, a significant increment in PD was observed in 24- to 28-day and adult groups within $5 \mathrm{~min}(P<0.005)$, but in 10 - to 14-day animals, the response was delayed and became significant only after $15 \mathrm{~min}$. The mean $I_{\mathrm{sc}}$ (at each interval) during the glucose-free period was greater in 10- to 14- than in 24- to 28-day $(P<0.01)$ and adult rabbits $(P<0.001)$. Similar differences occurred in the presence of glucose, which increased $I_{\mathrm{sc}}$ at all ages $(P<0.05)$. Tissue conductance across intestine from 10- to 14-day animals exceeded that of the older groups $(P<0.001)$ and fell with age; glucose increased conductance in intestine from 10- to 14-day and 24 - to 28-day animals $(P<0.01)$. Conductance across stripped adult intestine was greater than across full thickness intestine (see "Materials and Methods") but still less than we observed in full thickness from these younger animals.

\section{$\mathrm{Na}^{+}$TRANSPORT IN ISOLATED VILLUS CELLS (TABLE 2).}

Under basal conditions, total $\mathrm{Na}^{+}$efflux rate constants were significantly less in 3- to 5- and 10- to 14-day age groups than in 24- to 28-day and adult rabbits which did not differ. Glucose significantly stimulated the total $\mathrm{Na}^{+}$efflux rate constant in all age groups, although the total glucose stimulated rate constant remained significantly lower in the 3- to 5- and 10- to 14-day groups when compared to 24- to 28-day and adult groups. Passive efflux rate constants with and without glucose did not differ significantly between the age groups.

\section{ENZYME ACTIVITIES OF ISOLATED VILLUS CELLS (TABLE 3).}

When compared with data from adult animals, isolated villus cells from 3- to 5-day animals were deficient in $\mathrm{Na}^{+} \mathrm{K}^{+}$ATPase and sucrase and rich in lactase and thymidine kinase activities. $\mathrm{Na}^{+} \mathrm{K}^{+}$ATPase activity, lowest at 3 to 5 days, progressively increased with age, whereas thymidine kinase activity greatest at 3 to 5 days, progressively decreased. Lactase activity, high at 3 to

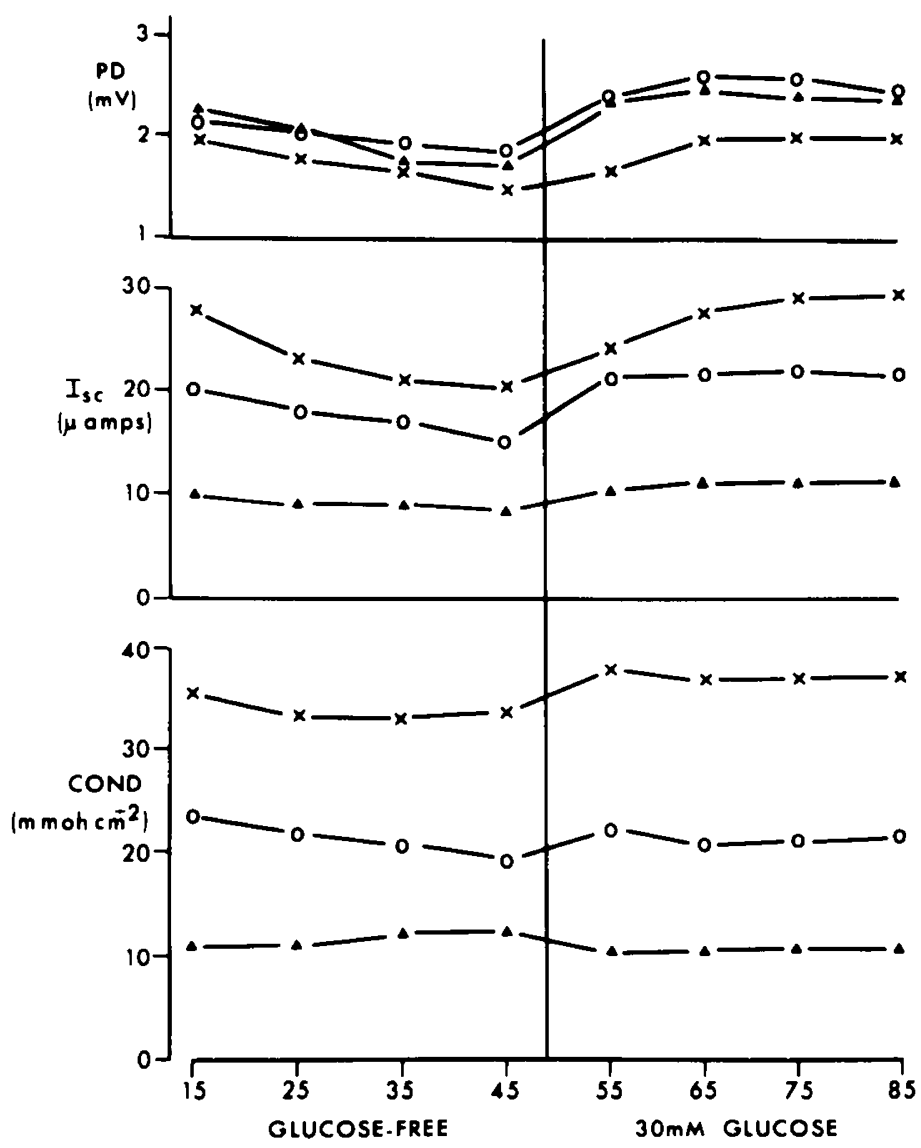

Fig. 1. Electrical data: $P D$, Short-circuit current $\left(I_{\mathrm{BC}}\right)$ and Conductance (COND) across proximal rabbit jejunum during postnatal development. Points, mean of 24 to 40 measurements. $X$, age 10 to 14 days; $O$, age 24 to 28 days; $\boldsymbol{\Lambda}$, adult animals.

Table 1. Sodium ion flux in short-circuit jejunal epithelium during postnatal development ${ }^{1}$

\begin{tabular}{|c|c|c|c|c|c|}
\hline Age group & $n^{2}$ & Study conditions & $\mathbf{J}_{\mathrm{m} *}$ & $\mathbf{J}_{\mathrm{sm}}$ & $\mathbf{J}_{\text {net }}$ \\
\hline \multirow[t]{2}{*}{ 10-14 days } & 10 & Glucose-free & $18.19 \pm 1.36$ & $18.48 \pm 1.20$ & $-0.29 \pm 0.59$ \\
\hline & & Glucose, $30 \mathrm{mM}(P)^{3}$ & $19.64 \pm 1.49(\mathrm{~ns})$ & $20.73 \pm 1.80(\mathrm{~ns})$ & $-1.09 \pm 0.46(\mathrm{~ns})$ \\
\hline \multirow[t]{4}{*}{ 24-28 days } & 8 & Glucose-free & $10.23 \pm 0.30$ & $8.78 \pm 0.22$ & $1.45 \pm 0.25$ \\
\hline & & $P^{4}$ & $<0.001$ & $<0.001$ & ns \\
\hline & & Glucose, $30 \mathrm{mM}(P)^{\mathrm{s}}$ & $12.24 \pm 0.45(<0.001)$ & $8.71 \pm 0.24(\mathrm{~ns})$ & $3.54 \pm 0.55(<0.001)$ \\
\hline & & $P^{4}$ & $<0.001$ & $<0.001$ & $<0.001$ \\
\hline \multirow[t]{4}{*}{ Adult } & 8 & Glucose-free & $7.15 \pm 1.27$ & $6.08 \pm 1.12$ & $1.05 \pm 0.53$ \\
\hline & & $P^{4}$ & $<0.001$ & $<0.001$ & ns \\
\hline & & Glucose, $30 \mathrm{mM}(P)^{3}$ & $10.94 \pm 0.84(<0.005)$ & $7.87 \pm 1.17(\mathrm{~ns})$ & $3.08 \pm 0.88(<0.001)$ \\
\hline & & $P^{4}$ & $<0.005$ & $<0.001$ & $<0.01$ \\
\hline
\end{tabular}

\footnotetext{
${ }^{1}$ Each value represents the mean flux \pm S.E. expressed in $\mu \mathrm{Eq} / \mathrm{cm}^{2} / \mathrm{hr}$.

${ }^{2} n$, number of animals; ns, not significant.

"Paired $t$-test of increments after $30 \mathrm{mM}$ glucose.

${ }^{4}$ Compared to flux value in 10- to 12-day-old age group.
} 
Table 2. $\mathrm{Na}^{+}$efflux from isolated enterocytes during postnatal development

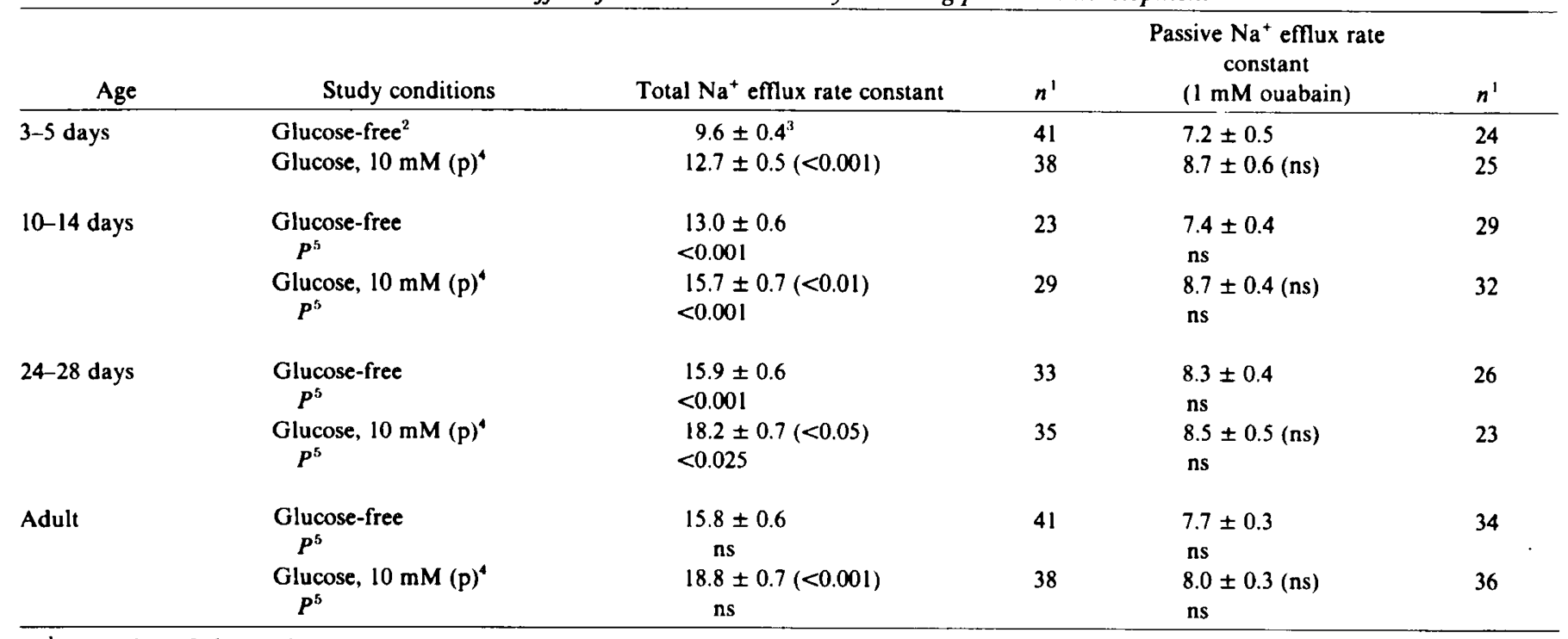

\footnotetext{
' $n$, number of observations.

${ }^{2}$ Mannitol, $10 \mathrm{mM}$.

${ }^{3}$ Mean \pm S.E.

${ }^{4}$ Compared to glucose-free conditions.

${ }^{5}$ Compared to value at preceding age.
}

Table 3. Enzyme activities in isolated villus enterocytes during postnatal development ${ }^{1}$

\begin{tabular}{|c|c|c|c|c|c|}
\hline Age group & $n^{2}$ & Lactase & Sucrase & Thymidine kinase & $\left(\mathrm{Na}^{+} \mathrm{K}^{+}\right)$ATPase \\
\hline 3-5 days & 8 & $77.6(55.0-109.6)$ & $0.67(0.05-9.21)$ & $15.5(11.9-20.2)$ & $6.2(5.3-7.2)$ \\
\hline 10-14 days & 6 & $75.9(64.5-89.1)$ & $0.06(0.05-0.08)$ & $9.8(8.0-11.9)$ & $8.6(7.4-9.8)$ \\
\hline$P^{3}$ & & ns & $<0.005$ & $<0.005)$ & ns \\
\hline 24-28 days & 6 & $60.8(34.7-104.7)$ & $24.6(17.8-33.9)$ & $9.0(6.6-11.9)$ & $13.9(12.3-15.5)$ \\
\hline$P^{3}$ & & ns & $<0.001$ & ns & ns \\
\hline$P^{4}$ & & ns & $<0.001$ & $<0.005$ & $<0.005$ \\
\hline Adult & 6 & $4.1(3.1-5.3)$ & $64.6(34.7-120.2)$ & $4.7(3.6-6.0)$ & $17.1(14.5-19.0)$ \\
\hline$P^{3}$ & & $<0.001$ & $<0.005$ & $<0.005$ & ns \\
\hline$P^{4}$ & & $<0.001$ & $<0.001$ & $<0.001$ & $<0.001$ \\
\hline
\end{tabular}

' Each value represents the antiolog of log mean and range of 1 S.E. Disaccharidase activities are expressed as $\mu$ moles of substrate hydrolyzed per min per $\mathrm{g}$ of protein, thymidine kinase activity as pmoles of thymidine phosphate per min per $\mathrm{mg}$ of protein, and $\left(\mathrm{Na}^{+} \mathrm{K}^{+}\right)$adenosine triphosphate (ATPase) activity as nmoles of inorganic phosphate per min per $\mathrm{mg}$ of protein.

$2 n$, number of animals.

${ }^{3}$ Compared to preceding younger age group.

${ }^{4}$ Compared to 3- to 5-day group.

5 days, remained high at 10 to 14 and 24 to 28 days, but was significantly decreased in adult animals. Sucrase activity was low in the younger age groups increased significantly between 10 to 14 days and 24 to 28 days and again after 24 to 28 days to the adult value.

\section{DISCUSSION}

Our data show that important alterations in intestinal $\mathrm{Na}^{+}$ transport, a major determinant of fluid absorption in the intestine, occur during postnatal development in the rabbit. Studied in isolated jejunal villus cells and across short-circuited intestinal segments, transcellular and paracellular $\mathrm{Na}^{+}$fluxes change with age. The isolated cell $\mathrm{Na}^{+}$efflux data indicate that whereas jejunal villus enterocytes from suckling animals can actively transport $\mathrm{Na}^{+}$under glucose-free conditions and can respond to glucose, the total efflux rate constant is less than in mature animals. Epithelial $\mathrm{Na}^{+} \mathrm{K}^{+}$ATPase activity, a reflection of the $\mathrm{Na}^{+}$pump in the basolateral membrane, also increases in villus cells as the animal matures. However, in the Ussing chamber studies, active trans- epithelial net $\mathrm{Na}^{+}$absorption could not be demonstrated in the suckling group in response to glucose. This lack of response to glucose in younger animals can not be attributed to tissue death in the chambers because histologic sections taken at the completion of the experiments showed the epithelium to be intact. Electrical data were stable throughout, and flux data from the individual $10-\mathrm{min}$ periods were consistant in each experiment. Glucose did cause an increment in $\mathrm{I}_{\mathrm{sc}}$ in tissue from suckling animals even though there was no measurable impact on net $\mathrm{Na}^{+}$ transport. In adult rat jejunum and guinea pig ileum, glucose has been demonstrated to stimulate neutral $\mathrm{NaCl}$ secretion simultaneously with electrogenic $\mathrm{Na}^{+}$absorption $(2,17,20)$. If present in suckling rabbit jejunum, such a mechanism could account for the apparent lack of glucose stimulated $\mathrm{Na}^{+}$absorption. An alternative explanation may be the increased permeability of intestine from suckling animals. Unidirectional fluxes and conductance were greatly increased in intestine from young compared with adult animals and active ion fluxes may have been overshadowed by marked paracellular shunting. In adult animals, 80 to $90 \%$ of the total conductance is accounted for by a diffusional movement 
via a shunt pathway (6), the electrophysiologic counterpart of the intercellular junctional complexes (18). If a similar proportion of shunting occurs in younger animals, our data indicate that these intercellular junctions are less "tight" in infant compared with adult intestine. Cooke and Dawson (4), studying ileum from 1- to 6-day old rabbits in Ussing chambers, also found increased unidirectional ion fluxes, high conductance, and failure of $\mathrm{Na}^{+}$ absorption to respond to an actively transported nonelectrolyte alanine, even though there was an effect on $I_{s c}$.

As expected, enterocytes from suckling animals were rich in total lactase activity and low in sucrase activity; after weaning, lactase activity decreased whereas sucrase activity increased $(10$, $13,15)$. In suckling animals, villus enterocytes were also relatively rich in thymidine kinase, an enzyme of DNA replication normally present in immature crypt cells $(9,21)$. The enzyme and ion transport characteristics of villus cells from suckling animals therefore are in some respects similar to those of normal crypt cells from mature animals, although in other respects they appear well differentiated with well-developed brush borders as evidenced by high lactase activity and the presence of glucose-coupled $\mathrm{Na}^{+}$ transport (9).

Intestinal $\mathrm{Na}^{+}$transport is clearly less efficient in the suckling rabbit. The capacity for active $\mathrm{Na}^{+}$transport is limited in early postnatal life and is associated with diminished activity of villus cell $\mathrm{Na}^{+} \mathrm{K}^{+}$ATPase, the enzyme system associated with active $\mathrm{Na}^{+}$transport in the basolateral membrane. Furthermore, the infant rabbit epithelium is comparatively leaky; transcellular passive $\mathrm{Na}^{+}$flux measured in isolated enterocytes is similar at all ages, but unidirectional $\mathrm{Na}^{+}$fluxes measured in intact tissue are increased, and conductance is greater in younger animals, strongly suggesting a comparatively large, low-resistance, extracellular ion flux. During the suckling period, the villus epithelium retains thymidine kinase activity and $\mathrm{Na}^{+} \mathrm{K}^{+}$ATPase activity is less. On the other hand, glucose-coupled $\mathrm{Na}^{+}$transport, a characteristic of differentiated villus epithelium, is intact early in life, suggesting that different aspects of intestinal epithelial function mature at different rates.

Because healthy young rabbits like healthy young humans, do not suffer excessive ion and fluid losses from their intestines, these immaturities of $\mathrm{Na}^{+}$transport appear not to be an important consideration for normal nutrition in early postnatal life. However, faced with enteric disease, like an enteritis in which $\mathrm{Na}^{+}$transport is compromised, limited transport function could become a serious handicap.

\section{REFERENCES AND NOTES}

1. Binder, H. J.: Mechanisms underlying the absorption of water and ions. Int. Rev. Physiol., 12: 285 (1977).

2. Binder, H. J., Powel, D. W., and Curran, P. F.: Effect of hexoses on ion transport in guinea pig ileum. Am. J. Physiol., 233: 538 (1972).
3. Breitman, T. R.: The feedback inhibition of thymidine kinase. Biochim. Biophys. Acta, 67: 153 (1963).

4. Cooke, H. J., and Dawson, D. C.: Transport characteristics of isolated newborn rabbit ileum. Am. J. Physiol., 234: 257 (1978).

5. Dahlqvist, A.: Method of assay of intestinal disaccharidases. Anal. Biochem, 7: 18 (1964).

6. Frizzell, R. A., and Schultz, S. G.: Ionic conductances of extracellular shunt pathway in rabbit ileum: influence of shunt on transmural sodium transport and electrical potential differences. J. Gen. Physiol., 59: 318 (1972).

7. Gall, D. G., Butler, D. G., Tepperman, F., and Hamilton, J. R.: Sodium ion transport in isolated intestinal epithelial cells. The effect of actively transported sugars on sodium ion efflux. Biochim. Biophys Acta., 339: 291 (1974).

8. Gall. D. G., and Chapman, D.: Sodium ion transport in isolated intestinal epithelial cells: comparison of the effect of actively transported sugars on sodium ion efflux in cells isolated from jejunum and ileum. Biochim. Biophys. Acta., 419: 314 (1976).

9. Gall, D. G., Chapman, D., Kelly, M., and Hamilton, J. R.: $\mathrm{Na}^{+}$transport in jejunal crypt cells. Gastroenterology. 72: 452 (1977).

10. Henning. S. G., and Kretchner, N.: Development of intestinal function in mammals. Enzyme (Basel), 15: 3 (1973).

11. Kelly, M. H., and Hamilton, J. R.: A micro-technique for the assay of intestinal alkaline phosphatase. Results in normal children and in children with celiac disease. Clin. Biochem., 3: 33 (1970).

12. Klemperer, H. G., and Haynes, G. R.: Thymidine kinase in rat liver during development. Biochem J., 108: 541 (1968).

13. Kolovsky, O.: Development of the function of the small intestine in mammals and man. (S. Karger, Basel, 1969).

14. Lowry, O. H., Rosenbrough, N. J., Farr, A. L., and Randall, R. J.: Protein measurement with the Folin phenol reagent. J. Biol. Chem.. 193: 265 (1951)

15. Moog. F.: Corticoids and the enzymatic maturation of the intestinal surface: alkaline phosphatase, leucylnaphtylamidase and sucrase. In: M. Hamburg. E. J. W. Barrington: Hormones in development, pp. 143-160. (Appleton-CenturyCrofts Meredith Corporation. New York, 1971).

16. McClung. H. J., Butler, D. G., Kerzner, B., et al.: Transmissible gastroenteritis: mucosal ion transport in acute viral enteritis. Gastroenterology, 70: 1091 (1976).

17. Munck, B. G.: Effects of sugar and amino acid transport on transepithelial fluxes of sodium and chloride of short-circuited rat jejunum. J. Physiol. (Lond.)., 223: 699 (1972).

18. Schultz. S. G., Frizzell. R. A., and Nellans, N. H.: Ion transport by mammalian small intestine. Ann. Rev. Physiol., 36: 51 (1974).

19. Schultz. S. G., and Zalusky, R.: Ion transport in isolated rabbit ileum. 1. Shortcircuit current and Na fluxes. J. Gen. Physiol., 47: 567 (1964).

20. Taylor, A. E., Wright. E. M.. Schultz. S. G., et al.: Effect of sugars on ion fluxes in intestine. Am. J Physiol., 214: 836 (1968).

21. Weiser, M. M.: Intestinal epithelial cell surface membrane glyco-protein synthesis: an indicator of cellular differentiation. J. Biol. Chem., 248: 2536 (1973).

22. Younoszai, M. K., Sapario, R. S., and Laughlin, M.: Maturation of jejunum and ileum in rats: water and electrolyte transport during in vivo perfusion of hypertonic solutions. J. Clin. Invest., 62: 271 (1978).

23. Dr. Shepherd was the recipient of the Anna Bradbury Springer Fellowship from the University of Toronto.

24. The present address of Dr. R. W. Shepherd is: The Department of Child Health, Royal Children's Hospital, Brisbane, Australia.

25. The authors thank Diane Chapman, Mary Perdue. Piya Drew, and Mahmood Khan for their expert technical assistance and Ene Kopti for secretarial assistance.

26. Requests for reprints should be addressed to: D. Grant Gall. Faculty of Medicine University of Calgary, Calgary. Alberta, Canada T2N IN4.

27. This research was supported by grants from the Medical Research Council of Canada.

28. Received for publication Feb. 6, 1979

29. Accepted for publication May 10, 1979. 